\title{
Recent Studies on Recreational Geography in Japan
}

\author{
Hideya ISHI * and Shigeru SHIRASAKA**
}

\begin{abstract}
The study examines recent geographical studies on recreation and tourism to identify future task. After reviewing the history and characteristics of Japanese recreation and tourism, geographical works can be categorized into studies of spatial organization, studies of landscape formation, and other studies (landscape evaluation and the perception of recreational resources).

In the field of spatial organization, geographers have identified recreational spaces centered on a city and complex recreational regions composed of different types of resorts. It is important in Japan, however, to develop further the study of urban recreation to examine recreational space. The field of landscape formation has accumulated more studies than that of spatial organization. The majority of previous studies, however, are preoccupied with hot spring and minshuku settlements and their perspective is economically oriented. Geographers can expand their scope into social or cultural geography and into environmental problems. Studies of environmental evaluation and recreational resources perception are in their early stages. On the whole, recreational geography in Japan is behind that of other developed countries in accepting such contemporary techniques as quantitative methods and environmental perception. The development of recreation and tourism in Japan, however, will increase the demand of geographical researches.
\end{abstract}

\section{Introduction}

Increasing mobility and leisure time have developed recreational activities into a booming business in modern industrial societies. Like other human activities, recreation has its geographical expressions. People demand space, create new landscapes, and transform space into a variety of functional organizations. The geographer's task is to analyse the pattern and process of these spatial organization. This study reviews recent geographical studies on recreation and tourism by Japanese geographers to identify unsolved fields of investigation.

Some geographers have already reviewed Japanese recreational geography. In 1976, AOKI and YamamuRa discussed previous studies by Japanese geographers. In the same year, YAMAMURA published a brief review in the English language. In 1984, TAKEUCHI made a similar report in GeoJournal. This present study focuses on the recreational studies of the post-war period, particularly the last decade, with reference to these previous studies.

\section{Characteristics of Japanese Recreation and Tourism}

Rapid development of recreational activities has led to an increase in geographical studies in different parts of the world. Reviews of these studies in the Western world have demonstrated distinct research trends by countries, partly because of different leisure activities. This section, therefore, summarizes some characteristics of Japanese recreational activities.

Some Japanese and foreign geographers have described these characteristics. In the International Geographical Congress of 1980, Yamamura and IsHi (1982), and the above-mentioned study of TAKEUCHI (1984) illustrated the distinctiveness of Japanese recreational activities. In 1980, ScHöLLER in West Germany reported Japanese recreational behaviour from a Westerner's viewpoint. In this report on Japanese tourism, ScHöLLER showed such characteristically Japanese phenomena as shortterm group tours, the custom of giving money to those who travel, and the accompanied duty to buy a souvenir. This present study occasionally refers to these previous studies.

Although some forms of recreational activities

\footnotetext{
* Institute of History and Anthropology, University of Tsukuba, Tsukuba-shi, Ibaraki 305 Japan.

** Department of Geography, Tokyo Gakugei University, Koganei-shi, Tokyo 184 Japan.
} 
probably began with the beginning of mankind, modern recreation is commonly regarded as a product of urban societies after the Industrial Revolution. It is more appropriate for geographers, however, to realize that leisure gained its geographical significance when it began to create its substantial landscape and genre de vie. From this standpoint, the origin of Japanese recreational activities dates as far back as the early eighteenth century (the middle Edo era) before the Industrial Revolution (Suzuki, 1967). This period was characterized by a stabilized government, public peace, development of a cash economy, and nationally improved road network system. People began to travel frequently. They established mutual cash-raising community organizations (kou) to visit distant well-known Shinto shrines and Buddhist temples. People also visited Kyoto and other historic places en route to these temples and shrines. Others began to visit hot springs for physical healing. Thus, religious-recreational towns appeared in front of famous temples or shrines, and around hot spring.

In the late nineteenth century after the Meiji Restoration of 1868 , similar recreational activities constantly developed during the Industrial Revolution. At the turn of the century, elites began to accept the custom of summering and wintering. Swimming and skiing were added to the variety of recreational activities. National Parks were established in the 1930s. The Ministry of Railways (Tetsudo-sho) actively developed transportation networks and the Japan travel Bureau energetically advertised recreation.

By 1955, Japan had recovered her economic standard to that of before World War II. Her rapid economic growth followed this reconstruction period, especially after 1960 . Leisure activities were popularized among every class of people. Some traditional characteristics, however, still remain today. Firstly, overnight trips do not usually extend to several days due to insufficient holidays. According to a survey of Japan Tourism Association, 56 per cent of overnight trips were just for one night and 24 per cent were for two nights in 1980 . Only 3.9 per cent of the trips extended to six or more nights. Although longterm tours and travelling abroad have recently been increased, the length of tours by the Japanese is still far behind that of the Europeans, especially of West Germans. Japanese resorts, therefore, are favourably located proximate to big cities.

Secondly, the majority of these tours are organized for groups of employees or community members to hurriedly visit hot springs or historic places. According to a survey of the Japan Tourism Association, it was only in the late 1970s that family or individual tours outnumbered group trips. Thirdly, hot spring still attract 30 per cent of all tourists, although leisure is growing more varied among younger generations. Large resorts, therefore, have been developed around hot springs. Fourthly, the majority of tours are conducted in the limited vacation periods of early May, middle August, and the period between late December and early January. Famous resorts are exceedingly crowded in these periods.

This uniformity and seasonality of tourism has induced the development of alternative recreational facilities in urban areas. Some examples, as TAKEUCHI (1984) has shown, include indoor amusement complexes and golf practicing fields. Since 1980, however, the increasing demand for shorter working hours and a five-working-days system is gradually changing government policy. Growing leisure time, the popularization of automobiles, and the development of the highway system will expand resort locations, give more variety to leisure activities and will make tourism an important social phenomenon.

\section{The Development of Recreational Geography}

The geography of recreation and tourism in Japan is behind both that in other developed countries and other fields of Japanese geography. АокI and YAMAMURA (1976) indicate the preoccupation of settlement studies and TAKEUCHI (1984) shows the economic orientation of the studies. The lack of comprehensive investigation is due not only to few statistics, few scholars, and traditional values that regard leisure as a sin, but also to some traditional characteristics of recreational activities previously mentioned.

Geographical studies of Japanese tourism first appeared in the $1920 \mathrm{~s}$, when the nationwide railroad network was completed and recreational activities were widely accepted (AOKI and YAMAMURA, 1976). These studies were mainly des- 
criptions of hot spring resorts.

From 1930 to the early 1940s, recreational studies dealt not only with hot spring resorts, but also with religious settlements, settlements for mountain climbers, and with swimming beaches. These studies, however, merely touched upon recreation and tourism as a part of settlement or regional geography. Although the analysis of nation-wide hot spring settlements by KIUCHI (1940) went far beyond a monograph of a small region, no related studies followed it.

Recreational studies have been increasing both in quantity and in variety since World War II, especially since 1960 , when tourism and recreation were popularized. In this section, recreational studies are categorized into (1) studies of spatial organization, (2) studies of landscape formation, and (3) other studies, which include landscape evaluation and the perception of recreational resources.

\section{Studies of spatial organization}

Unlike pre-war recreational geography, recent studies emphasize spatial aspects of tourism and attempt to systematize the discipline. Examples include a series of studies by IwaTA and his students during the 1950s and 1960s. The results were published in Kanko-Chiri Kenkyu (Studies on Tourist Geography) in 1968. Most of the articles in this book describe recreational facilities and the flow of tourists. Through the analysis, they endeavoured to identify functional regions of recreation and tourism with urban centres as their nodes. Although the movement of tourists is one of the central subjects of recreational geography, a few studies followed.

Other studies attempt to identify different aspects of recreational structues of space. One of the most notable studies was published by KoIKE (1960). Rapid urbanization in the 1960s gave geographers an abundant opportunity to analyze resorts around big cities and urban recreational regions. Through the analysis of recreational behaviour of Osaka citizens and resorts around Osaka, KoIKe identified recreational concentric zones, which included "Osaka City", "half-day tourist zones (one-hour trip one way)", "one-day tourist zones (three-hour trip)", and "overnight tourist zones (more than a three-hour trip)". He showed significantly different recreational forms, facilities, number of visitors, and landscapes among the four zones. TAKAHASHI and TAKABAYASHI (1978) studied social aspects and recreational zones of the people in Hamamatsu, a mid-size city in Shizuoka Prefecture. They reported that people travelled as far as 20 kilometers one way for a weekend trip (one-hour trip), which was considerably shorter than that of big cities. They, however, also indicated that weekday, weekend, and overnight recreational zones do not necessarily from simple concentric zones because of the heterogeneous distribution of social activities, economy, transportation routes, and resources.

Among recreational activities, overnight tourism changes landscapes and regional economy most forcibly. Overnight recreational zones are formed where people spend more money and time for transportation than for staying at the resort. Although it is difficult to generalize, they are normally located further than 100 to 150 kilometers from a big city, where it takes at least three hours of travel one way. YAmamura (Asaka and YAMAMURA, 1974) analyzed the origins of tourists in hot spring resorts to identify the sizes and characteristics of Tokyo, Osaka, and Nagoya recreational zones. YAMAMURA $(1967,1970 a)$ further analyzed the development of hot spring resorts in the Tokyo recreational zone through the flow of the tourists, lodging facilities, and recreational industries. He concluded that the growth of these resorts largely depended upon the transportation from Tokyo and recreational investment. YAMAMURA's comprehensive study analyzed not only the tourists' flow but also the landscape formation and recreation development processes, which will be discussed later.

IsHII $(1970,1980)$ chose minshuku as his subject. Minshuku are low-rent lodging facilities owned and managed by farmers or fishermen as their side business. Their numbers have multiplied since the $1960 \mathrm{~s}$, when recreation and tourism became popularized. IsHII identified that min shuku regions were developed as parts of recreational zones of such large cities as Tokyo. He classified minshuku regions into the mountain type based on skiing grounds and the beach type based on swimming beaches. The study of these two types of recreation were followed by SHIRASAKA, who specialized in the study of skiing grounds, and TANNO, who discussed the 
beach type recreation. Both studies focus on the development of recreational settlements, but SHIRASAKA $(1976,1984,1986)$ identified also the development of skiing grounds and their distribution in Japan. He interpreted the locations of skiing grounds with reference to natural resources, transportation between urban areas and skiing grounds, and socio-economic conditions. He indicated that the locations largely depended upon physical conditions (the amount of snow, kind of snow and topography), transportation between the railway station and the skiing ground, the investment for development, and the land ownership. TANNo $(1985,1987)$, on the other hand, studied the Kinki recreational zones and identified the minshuku type and the resort type as well as the traditional type around historic places as subtypes of the beach type resorts. He suggested that uni-functional resorts could not expand in this automobile age, but that multi-functional resort complexes are necessary for development. TANNO then examined his theory with empirical cases in Shima area of Mie Prefecture. Through analyzing different uni-functional resorts and functional relationships among these settlements, TANNO identified that different resorts with different resources and historical backgrounds formed a large recreation system. The identification of this spatial system, which is similar to that of industry or agriculture, is a significant discovery both for pure science and for applied geography.

Although the lack of long vacations in Japan induced the development of alternative recreational facilities in urban areas, this urban recreation has not been systematically examined. KoIKE (1960), TAKAHASH and TaKABAYASHI (1978) merely touched upon the subject as a part of urban geography. Other studies do not go beyond the descriptions of specific cases. For example, HatToRI (1979) showed the significance of leisure activities on urban formation in Cities and Amusement Quarters. Geographers have also published researches on sports facilities (SAITo et al., 1985), recreational agriculture (YAMAMURA and URA, 1982; TANABE, 1985), and green spaces in urban areas (Евато, 1975; Hashizume et al., 1982), and suburban golf courses (Osaki, 1976; Iwamoto 1978). Geographical investigation on urban recreational activities, however, falls far short of being exhaustive.

\section{Studies of landscape formation}

As Japanese recreational geography has traditionally been studied as a part of settlement or economic geography since before World War II, there are far more landscape studies than studies of spatial organization. The post-war studies were pioneered by Nомото. In the study of Myoko Kogen in 1961, he showed the necessity for historical examination of regional socio-economic conditions for the analysis of hot spring settlement formation and its characteristics.

Another notable earlier study is that of the recreational development of Sugadaira Kogen in central Japan by Iтон and Аокі (1962). They stated that the study of recreational development must go beyond the identification of such statistical results as recreational facilities or the number of tourists. They emphasized the importance of the decision-making process of the developer and the method of development. This study is persuasive because early Japanese recreational developments were characteristically carried out by city-based financial concerns, especially by railway companies.

YAMAMURA (1967) summarized these two pioneering suggestions into internal and external factor. He regarded transportation from big cities and investment by private railway companies as external factors, but such conditions of the communities as the right to hot springs, land ownership and the attitude of the community toward development were considered as internal factors. He empirically examined how the two types of factors affected the growth of hot spring resorts.

Since the late 1960s, geographers have been actively involved in the research of changing rural settlements due to the introduction of recreational business. Asakawa (1964) studied the development of minshuku settlements of Hakuba-mura in Nagano Prefecture. IsHII (1980) examined the formation of several minshuku settlements in Nagano Prefecture and Izu of Shizuoka Prefecture. Shirasaka (1986) analyzed skiing settlements in Shiga Kogen and Nozawa-Onsen. They discussed the development of recreational business in rural settlements from a variety of aspects, which include labour distribution between agriculture, fishery, and minshuku business, introduction of urban capital and response of people, tradi- 
tional land use and regional organizations, social classes, land ownership, policies of local governments and agriculture/fishery cooporatives, roles of the new residents, and the employment of recreational industries and its function in maintaining the population. Tanno (1987), Yamano (1980), and Matsuda (1980) approached the subject in a similar manner.

IsHII (1986) summarized a series of previous studies on the formation of minshuku regions so as to propose courses of action. He defind a Landschaft or region as a system composed of a locational-environmental subsystem, a socialeconomic-cultural subsystem, and groups of people as decision makers. He regarded the evolution of the Landschaft as a process in which people intensify the use of time and space through specialization to achieve a higher standard of living as a response to the changes in transportation and economic policy. IsHi chronologically examined regional characteristics, social structure, and the allocation of labour, land use, and resources between traditional industries and new recreational businesses to generalize them into descriptive model.

Some studies were more specific in their perspective. Konishi (1980), for example, investigated Myoko Kogen to identify the role of rural communities in recreational development and the evolution of these communities through commercialization. The growing demand of recreation and tourism after World War II made large-scale recreational development essential. Development, therefore, frequently occurred in communally used woodland and grassland areas around rural settlements as well as the seashore, for these areas could not support the thriving standard of living through traditional industries. Once developed, these traditional settlements quickly changed from agricultural or fishing communities to recreational communities. These spaces were developed mainly by private railway companies in the early period of large development. They have been, however, recently developed more actively by local governments or by the people for the improvement of their own standard of living. IKE (1986) thoroughly examined the social structure of two communities of Tateshina in Nagano Prefecture through analyzing the variation of recreational use of communal land.
Studies of landscape formation are numerous if we include settlements and regional geography dealing with recreational phenomena. Comprehensive studies on the impact of recreationalactivities on the region, land use, and socioeconomic structure include Ecology of Coastal Settlements by Birukawa and Yamamoto (1978) and a series of articles on highlands by IcHIKAWA (1966).

Other geographers have studied the origin and development of recreational cities. Such Japanese cities as Kyoto, Nara and Nikko depend largely upon the recreation business. Although more studies have dealt with these in terms of urban geography, some have emphasized their recreational aspects. Yamamura $(1970 \mathrm{~b}, 1978,1981)$, for example, analyzed such hot spring resorts as Atami, Kusatsu, and Beppu. TAKAHASH et al. (1974) examined Shimoda City of Izu. These studies empirically described recreationally directed urbanization through such indices as recreational capital, industries, facilities, specialization of these facilities, occupational structure, and the change of landscapes. Empirical studies, however, are too few to illustrate this geographical subject.

\section{Other studies}

Recent studies of recreational phenomena have become so various that some studies do not fall into the categories of spatial organization or landscape formation. In this section, we will review some important works that indicate new directions.

The first new direction is the study of landscape evaluation. The majority of the studies were done in the fields of civil engineering and landscape architecture. Mizoo $(1983,1987)$ is the only geographer who has pioneered the methodology of landscape evaluation. He eliminated psychological factors wherever possible and endeavoured to bridge the gap between human evaluation and objective geographical evaluation to develop the method of evaluating landscape objectively with as few factors as possible. This method divides recreational resources into geographical factors, simplifies them by such statistical methods as factor analysis, obtain the factors by using the judgments of specialists, and creates an equation for predicting landscape evaluation. Through empirical studies, Mizoo claimed that clearness, closeness, and surrounding landscape were 
important for such uni-resources as lakes. For multiple landscape resources, he suggested that the combination of rank, size, contrast, colour, and local colour can distinguish values of recreational resources.

Another notable study is by OGUCHI (1985), who examined the changing attitudes toward swimming throughout history as a case study of relative landscape perception. According to $\mathrm{O}_{\mathrm{GUCHI}}$, sea bathing was absent until it was introduced in the 1880 s in the Meiji era. Early sea bathing was for purpose of healing, which was an idea introduced from German medicine. Swimming beaches were established mainly along rocky coasts. Since the turn of the century, however, swimming became a leisure form and shifted to sand beaches. He thus identified that the same geographical location was changed from being "unfavoured" to "favoured" space by the introduction of new values. Through this empirical study, he showed changing values towards swimming beaches as a recreational resources.

Other studies investigated historic preservation (ICHIKAWA and SHIRASAKA, 1980), recreational fishing (KISHIDA, 1981), foreign visitors' flow in Japan (SHIRASAKA, 1982), previous studies on recreational and tourism outside Japan (IsHII, 1979), and the history of hot spring resorts (YAMAMURA, 1987).

\section{Future Task of Recreational Geography}

Although the studies of recreational geography have been increasing and becoming more varied, not enough research has yet been done on this subject. The first task of geographers is the better understanding of the phenomena. Another field of development is the vigorous introduction of such contemporary methods as quantitative technique and environmental perception.

For the study of spatial organization, we need an exhaustive examination of recreation and tourism in urban areas. Japanese people have established many recreational facilities in urban areas because they still have less leisure time than Western people. Systematic investigation on these various recreational activities is essential for the understanding of recreational space, although the lack of consistent data and the rapid change of the phenomena make this difficult. To study spatial organization, geographers also must develop the analysis of recreational behaviour and the flow of tourists. Although post-war Japanese recreational geography started with the study of the flow of tourists, this method has been largely neglected since then. The lack of reliability of the statistical data can probably be supplemented by questionaires. Time-space analysis, likewise, serves as an effective examination. The study of spatial organization must deal not only with the spatial pattern of resorts with urban centres as their core, but also with interaction among resorts. As the Japanese prefer visiting several resorts to staying at one place for a longer period of time, the analysis of spatial organization requires the study of the distribution of resorts by recreation type and the movement of the tourist who go to them. Tanno's study (1987) is an example which successfully illustrates Japanese recreational behaviour by showing the complex resort area consisting of several resorts of different resources and historical backgrounds.

The studies of landscape formation have been concentrated on the hot spring and minshuku settlements because Japanese people visited these places most often. Rapid motorization, however, has made tourism into casual behaviour and has produced variety in its recreational forms. These tendencies probably will continue in the future. It is necessary to study a variety of recreational landscape formation based upon various recreational forms, which include resort cities. Geographers also must examine different stages of recreationalization. Recreational geography must accept the perspective taken by the advanced field of rural geography, which examines de-agriculturalization in rural communities. This study did not review several studies which suggest this perspective because they are rural settlements studies rather than recreational geography. The study of landscape formation, as TAKEUCHI (1984) indicated, is too economically oriented. It is necessary to develop social or cultural perspectives. Geographers also must examine environmental problems in resort areas. Recreationalization of resorts areas changes traditional land use systems because of the inflow of capital and people from other places. Recreational activities often destory the environment, which could be preserved by traditional forms of economic activi- 
ties (IsHII, 1986).

The fields of landscape evaluation, recreational resource perception, and environmental preservation are in their early stages. Although the study of landscape evaluation was developed by Mizoo (1987), his analysis of geographical factors does not always correspond to the reality, probably because Japanese resorts tend to be determined more by fashion, psychology, and social factors. The gap between geographic model and reality must be bridged.

In general, Japanese recreational geography lacks applicational studies oriented towards regional planning. Although local governments frequently asked geographers for advice in recreational planning in the 1960 s, the lack of basic studies has led to little counselling today. It is certain, however, that the development of recreation and tourism in Japan will make the geographers responsibility greater.

\section{Acknowledgement}

The authors would like to express most sincerely their gratitude to Dr. Tadashi NAKAgawA, University of Tsukuba, for his kind advice and help in writing this paper.

(Received October 7, 1987)

(Accepted January 30, 1988)

\section{References}

AoKI, E. and J. YAMAMURA (1976): Perspective on Recreational Geography in Japan, 1924-1975, -A Bibliographical Study -. The Human Geography, 28(2), 57-80. (J)

ASAKA, Y. and J. YAMAMURA (1974): Kanko-chirigaku (Geography of Tourism and Recreation). Taimei-do, Tokyo, 234 p. (J)

ASAKAWA, R. (1964): An Impression of the Tourism in the Farming Regions of Snow-covered Highlands -A Case Study of Hakuba-mura, Nagano Prefecture-. Aichi Gakugei Daigaku Chirigaku Kenkyu Hokoku (The Geography Papers of Aichi Gakugei University), 21/22, 32-44. (J)

BiRUKAWA, Sh. and Sh. YAmamoto, (1978): Engan shuraku no Seitai (Regional Ecology of Coastal Settlements). Ninomiya-shoten, Tokyo, $245 \mathrm{p}$.

EвAто, A. (1975): Changes in Amenity Resources in Tokyo Wards Area. The Bulletin of Arts and Science, Meiji University, 98, 108-164. (J)

Hashizume, N., K. Matsuda, and T. Matsuo (1982): Socio-economic Effect Caused by the Installation of Musashi-kyuryo National Forest Park, Saitama Pre- fecture. Komazawa Geography, Science Reports of Department of Geography, The Komazawa university, 18, 131-149. (J)

HATTORI, K. (1979): Toshi to Sakariba (Cities and Amusement Quarters). Doyu-kan, Tokyo, 240 p.

ICHIKAWA, T. (1966): Koreichi no chirigaku (The Geography of Highlands in Japan), Reibun-sha, Nagano, $414 \mathrm{p}$.

ICHIKAWA, T. and Sh. SHIRASAKA (1980): Tourism Trends along Kiso Valley - Tourism Pattern in Old Settlements Designated as Cultural Assets-. Bulletin of Tokyo Gakugei University, Ser. III, 77-91. (J-E)

IKE, Sh. (1986): Changing Process of Land Use of Common Lands by the Development of Tateshina Resort Zone, Nagano Prefecture. Geographical Review of Japan, 59(3), 131-153. (J-E)

IsHII, H. (1970): Some Consideration of the Forming Process of Minshuku Regions in Japan. Geographical Review of Japan, 43(10), 607-622. (J-E)

IsHII, H. (1979): The Trend of Geographical Studies on Recreation and Tourism in West Germany. Tsukuba Studies in Human Geography, 3, 149-167. (J-E)

IsHII, H. (1980): The Formation of Minshuku Regions in Japan. Tsukuba Studies in Human Geography, 5, 115-150.

IsHII, H. (1982): Distribution of Major Recreational Regions in Japan. Frankfurter Wirtschafts- und Sozialgeographische Schriften, 41, 187-203.

IsHII, H. (1986): The Development of Minshuku Regions in Japan and Its Geographical Significance, In F. SCHAFFER (ed.): Angewandt Sozialgeographie -Karl Ruppert zum 60. Geburtstag, Augsburg, 79-90.

Iтон, T. and E. AoKI (1962): An Analysis of the Conditions in the Formation of Tourist Industries - The Case of Sugadaira Skiing Grounds-. Kanko-kenkyu (Leisure Studies), 69, 55-64. (J)

IwAmoto, H. (1978): A Geographical Study of Golf Courses in Japan -A Case Study in the Western Part of Saitama Prefecture-. The New Geography, 26(3), 39-64. (J)

IwATA, K. (ed.) (1968): Kanko-chiri Kenkyu (Studies on Tourist Geography). Meigen-shobo, Tokyo, 264 p.

KISHIDA, Sh. (1981): On the Relationship between Fishery for Tourism and Coastal Fishery -A Case Study in Ena, Yura-cho, Wakayama Prefecture-. Wakayama-chiri (Geographical Papers of Wakayama), 1, 13-21. (J)

KIUCHI, Sh. (1940): Problems of Hot Spring Settlements in Japan. Journal of Geography, 52, 110-125. (J-E)

KoIKE, Y. (1960): On the Types and their Regional Arrangement of Recreation Used by City-dwellers. Geographical Review of Japan, 33(12), 615-625. (J-E)

Konishi, M. (1980): The Forming Process and Inner Structure of minsuku Community - A Case Study of Suginosawa, Niigata Prefecture-. The Human Geography, 32(4), 24-39. (J-E)

MATSUDA, K. (1980): The Location of Skiing Grounds and Its Influence on the Surrounding Region - A Case Study in Iiyama, Nagano Prefecture-. Geographical 
Research of Graduate Students, Komazawa University, 10, 15-28. (J)

Mizoo, Y. and N. OoKuma (1983): Geographical Study of Landscape Evaluation -A Case Study of Lakes in Japan-. The Human Geography, 35(1), 40-56. (J-E)

Mizoo, Y. (1987): A Geographical Study on Evaluation of Landscape Resources. Science Report of Institute of Geoscience, University of Tsukuba, Sec. A, 8, 95-128.

Nomoto, K. (1961): The Development on the Slopes and Hot Spring Resorts around Mt. Myoko. Hiroshima Daigaku, Shigaku-kenkyu (The Journal of History, Hiroshima University), 81, 23-40. (J)

OGuchI, Ch. (1985): Sea Bathing and the Process of Its Acceptance in the Late 19th Century in Japan. The Human Geography, 37(3), 23-37. (J-E)

OsAKI, T. (1976): A Geographical Study on Golf Course in Japan. Geographical Review of Japan, 49(6), 400-408. (J-E)

SAITOH, I., M. KanNo, and K. TANaKa (1985): The Distribution of Sports Facilities in the Western Suburbs of Tokyo. Annual Reports of Institute of Geoscience, University of Tsukuba, 11, 4-9.

SCHÖLLER, P. (1980): Tradition und Moderne in Innerjapanischen Tourismus. Erdkunde, 34, 134-150.

SHIRASAKA, Sh. (1976): The Location and the Development of Skiing Grounds at Nozawa Spa Village, Nagano Prefecture, Central Japan -A Geographical Study on the Skiing Grounds in Japan-. Geographical Review of Japan, 49(6), 341-360. (J-E)

SHIRASAKA, Sh. (1982): Foreign Visitors' Flow in Japan. Frankfurter Wirtschaft- und Sozialgeographische Schriften, 41, 205-218.

SHIRASAKA, Sh. (1984): Skiing Grounds and Ski Settlements in Japan. Geographical Review of Japan (Ser. B), 57(1), 68-86.

SHIRASAKA, Sh. (1986): Sukii to sanchi-shuraku (Skiing and Ski Settlements in Japan). Meigen-shobo, Tokyo, $159 \mathrm{p}$.

SuZUKI, Y. (1967): Tourism in Japan. Festschrift Leopold G. Scheidl zum 60. Geburstag, II Teil, Wien 204-218.

TAKAhashi, N., M. KanNo, and K. KobaYASHI (1974): Urbanization in a Small City through the Development of Tourism and Recreation - A Case of Shimoda, Japan-. Tokyo Geography Papers, 18, 119-152. (J-E)

TAKAHASHI, N. and K. TAKABAYASHI (1978): Leisure Activity Spaces in the City of Hamamatsu. Tsukuba Studies in Human Geography, 2, 95-108. (J-E)

TAKEUCHI, K. (1984): Some Remarks on the Geography of Tourism in Japan. GeoJournal, 9, 85-90.

TANABE, K. (1985): A Study on the Change from Agricul- ture Areas to Recreational Areas - Exemplifying the Case of Strawberry Picking in Hiro, Arino-cho, KitaWard, Kobe-shi-. Humanities Review (The Journal of the Literary Association of Kwansai Gakuin University), 35(3), 137-163. (J)

TANNO, A. (1985): The Formation of Minshuku Type Tourist Areas along Coastal Regions - The Example of Osatsu Settlement in Toba City, Mie Prefecture-. Geographical Review of Japan, 58(1), 19-38. (J-E)

TAnno, A. (1987): Formation of Coastal Tourist Area in the Kinki District. Unpublished Doctoral Dissertation, University of Tsukuba, $139 \mathrm{p}$.

YAMAMURA, J. (1967): Regional Differentiation of the Development Stages of the Hot Spring Resorts in the Tokyo Tourist Region. Geographical Review of Japan, 40(1), 625-643. (J-E)

YAMAMURA, J. (1970a): Tourism and Recreational Developments around Tokyo. In Special Publication No. 2 of Japanese Geographers: Japanese Cities, Tokyo, 63-72.

YAMAMURA, J. (1970b): Formation of Atami and Its Functions as a City of Hot Spring and Sightseeing). Toyokenkyu (Bulletin of the Institute of Oriental Studies of Daito-bunka University), 22, 38-72. (J)

YAMAMURA, J. (1976): Geography of Tourism and Recreation, In Sh. KIUCHI (ed.): Geography in Japan. Univ. of Tokyo Press, Tokyo, 201-204.

YamamuRA, J. (1978): Changing Process of Kusatsu Hot Spring Settlement from Health Resort to Tourist Resort. The Bulletin of the Faculty of Education, Chiba University, 27, 191-215. (J)

YamamuRA, J. (1981): Regional Development of Beppu Hot Spring Tourist City, Oita Prefecture. The Bulletin of the Faculty of Education, Chiba University, 30, 129-155. (J)

YAMAMURA, J. and T. URA (1982): The Trend of Tourist Farms in Urbanized Region along the River Tama, Kawasaki City, Kanagawa Prefecture. The New Geography, 30(2), 1-18. (J-E)

YAmAMURA, J. (1982): The Courses of Development of Tourism and Recreation in Japan. Frankfurter Wirtschafts- und Sozialgeographische Schriften, 41, 175-185.

YAMAMURA, J. (1987): Nippon no onsen-chi-Sono hattatsu, genjo to arikata - (Spa Settlements in Japan The Development and the Present Conditions-). Japan Spa Association, Tokyo, 237 p.

YAMANO, A. (1980): A Study of the Location for "Minshuku" in Otari Mountainous Village, Nagano Prefecture. Geographical Research of Graduate Students, Komazawa University, 10, 3-14. (J) 


\title{
日本における近年の観光・レクリェーション地理学の発達
}

\author{
石井 英也 $^{*} \cdot$ 白坂 蕃**
}

この報告の目的は，これまでの研究成果を踏まえ，と くに最近10年間ほどの業績に注目しながら，わが国にお ける観光・レクリェーション地理学の特徵と課題を検討 することにある。ここではまず，わが国における観光・ レクリェーション活動の発達とその特徴を簡単に概観し た後, それらに関する地理学的研究を空間構造論的研究, 景観形成論的研究，その他（景観評価や観光資源の認知 などに関する研究）に分類して，検討した.

その結果, 空間構造論的研究の範疇では, 都市を中心 とした観光空間の形成に関する研究のほか, 観光地の専 門分化に基づく複合観光地域形成論など，注目される主 張がなされたりして，少しづつ研究成果が蓄積されてき た。しかし，観光空間を把握するには，とくにわが国で は重要な, 都市内やその周辺地域の観光・レクリェーシ ヨンに関する研究の進展が不可欠である。また，景観形
成論的研究は, 空間構造論的研究に比べると研究蓄積が はるかに豊富である。しかし，それらの多くは温泉集落 と民宿集落に研究対象が限られており, その観点も経済 地理学的考え方への傾斜が目立ち, 社会地理や文化地理 学的観点, あるいは環境問題の視点がもっと導入される べきである。その他，景観評価や観光資源の認知に関し ても研究の萌芽がみられるが, 全体として見ると, わが 国の観光・レクリェーション地理学研究の現状は, 計量 化や環境認知など, 地理学で近年よく用いられている研 究手法の導入が遅れている。また，欧米諸国に比べると， わが国における観光・レクリェーション地理学的研究 は, 地域計画などを志向した応用地理学的研究も少ない。 現在の社会や経済の趨勢を考えると，わが国では観光・ レクリェーション現象がますます重要になり, それに応 じて地理学者の任務も重くなることが明らかである。 